\title{
PENGARUH MODEL PEMBELAJARAN LOGAN AVENUE PROBLEM SOLVING (LAPS-HEURISTIK) TERHADAP HASIL BELAJAR SISWA KELAS VII SMP NEGERI 2 LANGSA \\ Suryani $^{1}$ Iqbal $^{2}$ \\ ${ }^{1}$ Alumni Jurusan/Prodi Pendidikan Matematika IAIN Langsa \\ Email : suryani@gmail.com \\ ${ }^{2}$ Dosen Jurusan/Prodi Pendidikan Matematika IAIN Langsa \\ Email: iqbal_math@iainlangsa.ac.id
}

\begin{abstract}
ABSTRAK
Penelitian ini bertujuan untuk mengetahui: pengaruh model pembelajaran Logan Avenue Problem Solving (LAPS-Heuristik) terhadap hasil belajar siswa kelas VII. Penelitian ini dilakukan di SMP Negeri 2 Langsa pada semester ganjil tahun ajaran 2015-2016. Populasi dalam penelitian ini adalah seluruh siswa kelas VII SMP Negeri 2 Langsa. Dari hasil pengembilan sampel dengan menggunakan teknik random sampling cara acak kelas, diperoleh kelas VII-7 dengan jumlah 26 orang siswa sebagai kelas eksperimen, dan kelas VII-6 dengan jumlah 26 orang siswa sebagai kelas kontrol. Jenis penelitian yang digunakan dalam penelitian ini adalah penelitian kuantitatif. Pengumpulan data menggunakan instrument berupa tes uraian yang terdiri dari 5 soal. Analisis data untuk menguji hipotesis dalam penelitian ini menggunakan uji regresi dengan taraf $(\alpha)=0,05$ dan $\mathrm{dk}=(\mathrm{n} 1+\mathrm{n} 2-2)$. Dari hasil pengujian diperoleh bahwa $t_{\text {hitung }}=3,168$ dan nilai $t_{\text {tabel }}=2,732$. Karena $t_{\text {hitung }}>t_{\text {tabel }}$, maka dapat ditarik kesimpulan bahwa ho ditolak dan ha diterima, sehingga dapat disimpulkan bahwa model pembelajaran Laps-Heuristik sangat efektif dalam masalah-masalah yang terdapat di materi aljabar di kelas VII SMP Negeri 2 Langsa.
\end{abstract}

Kata Kunci: Model Pembelajaran LAPS-Heuristik Pada Hasil Belajar

\section{PENDAHULUAN}

Peningkatan mutu pendidikan merupakan suatu masalah yang harus di perhatikan karena pendidikan memegang peranan penting bagi kelangsungan hidup manusia. Peningkatan mutu pendidikan dari tahun ketahun selalu diupayakan, baik pendidikan pada tingkat dasar, menengah, dan perguruan tinggi. Upaya untuk meningkatkan mutu pendidikan dipengaruhi oleh kurikulum, buku pelajaran, media belajar, model pembelajaran, dan sistem evaluasi. Meningkatkan mutu pendidikan sama hlmnya dengan meningkatkan kualitas belajar siswa,meningkatkan kualitas belajar siswa tergantung pada komponen-komponen antara lain siswa, kurikulum, guru, metode pembelajaran, sarana dan prasarana serta lingkungan.

Herman hudojo, megemukakan bahwa: Matematika dapat diartikan dengan ide-ide (gagasan-gagasan), struktur- struktur dan hubungan-hubungan yang diatur secara logis sehingga matematika itu berkaitan dengan konsep-konsep abstrak. Ia melanjutkan, matematika dikembangkan berdasarkan atas alasan logis dengan menggunakan pembuktian deduktif. ${ }^{1}$

\footnotetext{
${ }^{1}$ Hudojo, Herman.1990.Strategi Mengajar Belajar Matematika. Malang:IKIP Malang
} 
Proses pembelajaran dapat berjalan efektif jika seluruh komponen yang berpengaruh saling mendukung dalam rangka mencapai tujuan, misalnya ketertarikan siswa dalam belajar, memotivasi siswa, penggunaan metode pembelajaran yang bervariasi dan teknik guru dalam mengajar dikelas mempengaruhi proses dan hasil belajar siswa.

Menurut Trianto, "Keberhasilan penyelenggaraan pendidikan formal secara umum dapat diindikasikan apabila kegiatan belajar mampu membentuk pola tingkah laku peserta didik sesuai dengan tujuan pendidikan, serta dapat dievaluasi melalui pengukuran dengan menggunakan tes dan nontes". 2 Untuk menghasilkan proses pembelajaran yang baik hendaknya guru melibatkan siswa untuk berpartisipasi dalam proses belajar.

Matematika merupakan salah satu mata pelajaran disekolah yang cukup memegang peran penting dalam membentuk siswa menjadi berkualitas, karena matematika merupakan suatu sarana berfikir untuk mengkaji sesuatu secara logis dan sistematis. Karena itu, perlu adanya peningkatan mutu pendidikan matematika. Salah satu hlm yang harus diperhatikan adalah peningkatan hasil belajar matematika siswa di sekolah. Di sekolah, matematika merupakan salah satu mata pelajaran yang masih dianggap sulit untuk dipahami siswa. Oleh karena itu dalam proses pembelajaran matematika diperlukan suatu model pembelajaran yang bervariasi. Namun kenyataan yang terjadi saat ini adalah penguasaan siswa terhadap materi pelajaran matematika masih tergolong rendah jika dibandingkan dengan materi pelajaran lainnya di sekolah. Kondisi seperti ini terjadi pula pada SMP Negeri 2 Langsa.

Dominan guru dalam proses pembelajaran menyebabkan kecenderungan siswa lebih banyak menunggu sajian guru daripada mencari dan menemukan sendiri pengetahuan dan keterampilan, siswa hanya mencontohkan dan mencatat bagaimana cara menyelesaiakan soal setelah dikerjakan oleh gurunya,jika mereka diberikan soal yang berbeda dengan soal latihan, mereka mulai merasa bingung karena tidak tahu harus mulai darimana mereka menyelesaikannya, para siswa jarang sekali bertanya jika ada hlm-hlm yang belum jelas atau kurang dipahami, siswa juga kurang memiliki keyakina untuk menyelesaikan soal-soal individu atau maju kedepan kelas.

Untuk mengatasi masalah yang ada di SMP Negeri 2 Langsa, maka guru dapat menerapkan model pembelajaran inovatif dalam pembelajaran matematika. Pembelajaran matematika yang dapat meningkatkan hasil belajar adalah pembelajaran yang dapat memecahkan masalah oleh siswa dalam penyelesaiannya.

Sebagaimana yang dikemukakan oleh Slameto "Guru harus menggunakan banyak metode pada waktu mengajar, variasi metode mengakibatkan penyajian bahan ajaran lebih menarik perhatian siswa, mudah diterima siswa, dan kelas menjadi hidup". ${ }^{3}$ Untuk menanggulangi hlm tersebut seharusnya pengaruh metode mengajar yang dilakukan guru harus tidak lagi berpusat pada guru, tetapi berpusat pada siswa. Oleh karena itu, guru harus memahami berbagai bentuk model pembelajaran yang sesuai.

\footnotetext{
${ }^{2}$ Trianto, Model Pembelajaran Terpadu, (Jakarta: Bumi Aksara, 2012), hlm 5.

${ }^{3}$ Slameto, Belajar dan Faktor-Faktor yang Mempengaruhi, (Jakarta: Rineka Cipta, 2003), hlm. 92
} 
Upaya dalam meningkatkan hasil belajar tersebut dapat diterapkan suatu model pembelajaran yang inovatif dalam belajar yaitu model pembelajaran Logan Avenue Problem Solving (LAPS-Heuristik). LAPS-Heuristik mempunyai tujuan dan kelebihan yaitu memungkinkan siswa belajar lebih aktif, karena memberikan kesempatan mengembangkan diri, fokus pada pemecahan masalah dan materi Aljabar serta diharapkan mampu memecahkan masalah sendiri dengan menemukan (discovery) dan bekerja sendiri.

Beberapa hasil penelitian terdahulu yang berkaitan dengan penerapan model pembelajaran LAPS-Heuristik memberikan dampak yang positif terhadap hasil belajar siswa. Hasil penelitian I Made,dkk menunjukkan bahwa ada perbedaan yang signifikan antara kelas eksperimen dan kelas kontrol yang berdasarkan rata-rata hasil belajarnya. Respon siswa terhadap penerapan model LAPS-Heuristik adalah positif. ${ }^{4}$

Berdasarkan latar belakang yang telah diuraikan di atas, maka Penulis akan mengadakan penelitian tentang pengaruh model pembelajaran LAPS-Heuristik untuk meningkatkan hasil belajar siswa melalui pembelajaran matematis. Pembelajaran yang akan dilakukan adalah pembelajaran yang memberikan suatu tindakan melalui alternativ pembelajaran yang berorientasi pembelajaran yang berpusat ke siswa yang diharapkan dapat meningkatkan hasil belajar siswa.

\section{KAJIAN TEORI}

Pembelajaran matematika ialah cara berfikir yang digunakan untuk memecahkan berbagai jenis persoalan dalam kehisupan sehari-hari dengan menggunakan bahan ajar yang cocok dengan materi yang akan disampaikan.

Dari penjelasan di atas dapat disimpulkan bahwa pembelajaran matematika adalah proses interaksi antara guru dan siswa yang melibatkan pengembangan pola berfikir dan mengolah logika pada suatu lingkungan belajar yang sengaja diciptakan oleh guru dengan berbagai metode agar program belajar matematika tumbuh dan berkembang secara optimal dan siswa dapat melakukan kegiatan belajar secara efektif dan efisien. Selain interaksi yang baik antara guru dan siswa tersebut, factor lain yang menentukan keberhasilan pembelajaran matematika adalah bahan ajar yang digunakan dalam proses pembelajaran tersebut.

Model secara kaffah dimaknakan sebagai sebagai suatu objek atau konsep yang digunakan untuk mempresentasikan sesuatu hlm. ${ }^{5}$ Sedangkan secara pembelajaran adalah usaha sadar dari seorang guru untuk membelajarkan siswanya (mengarahkan interaksi siswa dengan sumber belajar lainnya) dalam rangka mencapai tujuan yang diharapkan.

${ }^{4}$ I Made Adiarta Gusti, dkk. Pengaruh model pembelajaran LAPS-Heuristik terhadap hasil belajar TIK Ditinjau dari kreatifitas siswa kelas VIII SMP Negeri 1 Payangan. (jurnal penelitian: Singaraja Universitas Ganesha) Vol 3, hlm 201-211 2010), hlm. 8 .

5 Trianto, Mendesain Model Pembelajaran Inofatif Progressif, (Jakarta : Prenada Media Group, 
Pada dasarnya suatu model pembelajaran dapat dirasakan baik apabila telah diuji coba untuk mengajarkan materi pelajaran tertentu. Oleh karena itu, dalam memilih suatu model pembelajaran harus memiliki berbagai pertimbangan, misalnya materi pelajaran, tingkat perkembangan siswa dan fasilitas-media yang tersedia sehingga tujuan pembelajaran yang telah ditetapkan dapat tercapai.

Heuristik adalah rangkaian pertanyaan yang bersifat tuntunan dalam rangka solusi masalah. LAPS (Logan Avenue Problem Solving) dengan kata tanya apa masalahnya, adakah alternatif, adakah bermanfaat, adakah solusinya, dan bagaimana sebaiknya mengerjakannya. ${ }^{6}$ Heuristik berfungsi mengarahkan pemecahan masalah (dalam hlm ini siswa) untuk menemukan solusi dari masalah yang diberikan. Polya mendefinisikan heuristik sebagai suatu cara membantu untuk menemukan pemecahan. Logan Avenue Elementary School mengusulkan heuristik untuk menyelesaikan masalah, meliputi: (1) what is the problem? (2) what are the alternatives?(3) what are the advantages or disadvantages? (4) what is a sollution? (5) how well is it working?. Dan untuk selanjutnya heuristik tersebut dinamakan Logan Avenue Problem Solving (LAPS) Heuristic.

Polya menyatakan bahwa : "An importain part in the series of question that are guiding in order to find a solution to the problem is the choice of problem-solving strategies that comes with applying (1) to read and understand the situasion (2) explore ideas, (3) selecting strategis, (4) search for a solution, (5) check to see if it solver the problem", artinya sebuah bagian penting dalam rangkaian pertanyaan yang bersifat tuntunan untuk mencari masalah adalah pemilihan strategi pemecahan masalah ya ng dilengkapi dengan menerapkan (1) membaca dan memahami situasi, (2) mengekplorasi ide, (3) memilih stratregi, (4) mencari solusi, (5) memeriksa untuk melihat apakah itu memecahkan masalah.

\section{METODE PENELITIAN}

Dalam penelitian ini peneliti akan menggunakan jenis penelitian kuantitatif dengan metode eksperimen. Data yang diperlukan dalam penelitian ini diperoleh melalui tes uraian. Pada penelitian ini, pemberian tes dimaksudkan untuk mengukur kemampuan kemampuan siswa dalam memperoleh setelah mengikuti pembelajaran dengan menggunakan model Laps-Heuristik. Tes kemampuan awal diberikan pada awal kegiatan penelitian untuk mengidentifikasi kekurangan atau kelemahan siswa dalam materi aritmatika sosial dan diakhir pembelajaran setelah memberikan perlakuan pada kedua kelas diberikan post tes untuk mengetahui peningkatan hasil belajar siswa. Dengan kata lain, tes disusun dan dilakukan untuk mengetahui tingkat kemampuan hasil belajar siswa pada akhir proses pembelajaran. sebelum tes digunakan tes harus diuji coba kepada siswa kelas VIII yang telah mempelajari materi tersebut dengan tujuan tes

\footnotetext{
${ }^{6}$ Ngalimun. Strategi dan Model Pembelajaran. (Yogyakarta: Aswaja Pressindo, 2011), hlm 177

7 Rasben,g.,dkk. 2001. Pengaruh model Pembelajaran LAPS-Heuristik Terhadap Hasil Belajar Tik Ditinjau Dari Kreativitas Siswa Kelas VIII SMP negeri 1 payangan. Jurnal program pascasarjana universitas pendidikan Ganesha tersedia di http: //pasca.undiksha.ac.id/e-journal/index.php/ jurnal_ep/article/ view/ 1147pengaruh model pembelajaran laps [diakses 26-022016]. 
harus valid dan reliabel. Analisis data dimulai menelaah seluruh data yang ada dari berbagai sumber yaitu tes. Teknik analisis data merupakan tahap yang paling penting dalam suatu penelitian, adapun untuk menganalis data, penulis menggunakan statistik hipotesis uji regresi pada taraf signifikan $5 \%(\alpha=0,05)$ sebelum data diuji regresi terlebih dahulu di uji persyaratan analisis normalitas dan homogenitas.

\section{ANALISIS DATA PENELITIAN DAN PEMBAHASAN}

Berdasarkan penelitian pada awal pembelajaran kemampuan siswa dalam memperoleh hasil belajar pada materi aljabar masih rendah. Hlm ini disebabkan bahwa guru masih menggunakan strategi belajar lama yakni menggunakan metode ceramah (pembelajaran konvensional). Anggapan ini didasarkan pada perolehan nilai tes awal siswa sebagai data awal yang akan dijadikan kajian penelitian. Dari kelas eksperimen diperoleh nilai rata-rata sedikit dan nilai rata-rata kelas kontrol hampir sama dengan kelas ekperimen yang dapat dikategorikan belum mencapai hasil belajar yang sesuai.

Setelah dilakukan proses pembelajaran dengan menggunakan model pembelajaran laps-heuristik, didapat bahwa kemampuan siswa dalam memperoleh hasil belajar lebih baik daripada kemampuan siswa dalam memperoleh hasil belajar dengan menggunakan pembelajaran konvensional. Siswa lebih siap dalam menyelesaikan soal yang berkaitan dengan kehidupan dan bidang ilmu lain, dan siswa pun mampu menggunakan konsep materi yang pernah dipelajari dalam penyelesaian soal materi lain.

Setelah diperoleh bahwa rata-rata hasil belajar siswa yang diajarkan dengan menggunakan model pembelajaran laps-heuristik lebih tinggi dari hasil belajar siswa yang diajar dengan pembelajaran konvensional. Hasil belajar siswa dalam memperoleh hasil belajar kelas eksperimen diperoleh nilai rata-rata bagus. Sedangkan dalam memperoleh hasil belajar siswa kelas kontrol diperoleh nilai rata-rata sebesar bagus. dengan hasil pengujian hipotesis diperoleh $t_{\text {hitung }}>t_{\text {tabel }}$ yaitu 2,732 $>3,168$ pada taraf $\alpha=0,05$. Kemudian analisis hasil akhir siswa diperoleh $t_{\text {hitung }}=3,168$ dengan $t_{\text {tabel }}$ yaitu 2,732 pada taraf signifikan $\alpha=0,05$, sehingga dapat diperoleh $t_{\text {hitung }}>t_{\text {tabel }}$ maka dapat dinyatakan tolak Ho sehingga diperoleh bahwa terdapat efektifitas model pembelajaran 
laps-heuristik dalam memperoleh hasil belajar pada siswa kelas VII SMP Negeri 2 Langsa.

\section{KESIMPULAN}

Berdasarkan hasil penelitian dan pembahasan pada bab IV, dapat ditarik kesimpulan bahwa terdapat efektifitas dari penggunaan model pembelajaran LAPS-heuristik dalam memperoleh hasil belajar siswa pada materi aljabar di kelas VII SMP Negeri 2 Langsa tahun ajaran 2014/2015. Hlm ini ditunjukkan dengan rata-rata pos test kelas yang menggunakan pembelajaran dengan model pembelajaran laps-heuristik lebih tinggi dibandingkan dengan siswa yang menggunakan pembelajaran konvensional.

\section{DAFTAR PUSTAKA}

Asep Jihad dan Abdul Haris, 2008. Evaluasi Pembelajaran. Yogyakarta: Multi Pressindo Arikunto, Suharsimi. 2005. Dasar - dasar Evaluasi Pendidikan, Jakarta : Bumi Aksara

Amin suyitno, Dasar-Dasar Dan Proses Pembelajaran Matematika 1", makalah,(semarang : universitas negeri semarang, 2004), hlm.1,t.d.

http://arinimath.blogspot.com/2008/02/defenisi-matematika. html.

Gusti, I Made Adiarta, dkk. 2014. Pengaruh Model Pembelajaran Laps-Heuristic terhadap Hasil Belajar TIK Ditinjau dari Kreativitas Siswa Kelas VIII SMP Negeri 1 Payangan. Jurnal Penelitian, (Singaraja: Universitas Ganesh, Program Studi Penelitian dan Evaluasi Pendidikan)

Hudojo, Herman.1990. Strategi Mengajar Belajar Matematika. Malang: IKIP Malang Husaini Usman, Purnomo Setiady. 2006. Pengantar Statistika. Jakarta: Bumi Aksara, Made Adiarta Gusti, dkk. Pengaruh model pembelajaran LAPS-Heuristik terhadap hasil belajar TIK Ditinjau dari kreatifitas siswa kelas VIII SMP Negeri 1 Payangan. (jurnal penelitian: Singaraja Universitas Ganesha)

Mudjiono, Belajar dan Pembelajaran, (Jakarta : Rineka Cipta,2006)

M.Cholik Adinawan sugijono, Buku paket Matematika SMP/MTs.S Kelas VII, 2006.Erlangga

Ngalimun. Strategi dan Model Pembelajaran. (Yogyakarta: Aswaja Pressindo, 2011)

Ngalimun. Strategi dan Model Pembelajaran. (Yogyakarta: Aswaja Pressindo, 2011)Nurkancana, dkk, Evaluasi Hasil Belajar, (Surabaya : Usaha Nasional, 1990),

Rasben,g.,dkk. 2001. Pengaruh model Pembelajaran LAPS-Heuristik Terhadap Hasil Belajar Tik Ditinjau Dari Kreativitas Siswa Kelas VIII SMP negeri 1 payangan. Jurnal program pascasarjana universitas pendidikan Ganesha tersedia di http: //pasca.undiksha.ac.id/ejournal/index.php/ jurnal_ep/article/ view/ 1147pengaruh model pembelajaran laps [diakses 26-022016].

Riduwan. 2004. Belajar Mudah Penelitian untuk Guru-Karyawan dan Peneliti Pemula. Bandung: Alfabeta

Rusman, Model-model Pembelajaran, (Jakarta : Raja Grafindo Persada, 2010).

Slameto, Belajar dan Faktor-Faktor yang Mempengaruhi, (Jakarta: Rineka Cipta, 2003

Slameto, Belajar dan Faktor-Faktor yang Mempengaruhi, (Jakarta: Rineka Cipta, 
2003).

Syaiful Bahri Djamarah, Psikologi Belajar, (Jakarta : Rineka Cipta, 2008),

Syaiful Sagala, Konsep dan Makna Pembelajaran, (Bandung : Alfabeta, 2009

Sudjana. 2001. Metode Statistika. Bandung: Tarsito

Suryabrata, Sumadi. 2011. Metodologi Penelitian. Jakarta: PT. RajaGrafindo Persada

Sudjana. 2001. Metode Statistika. Bandung: Tarsito

Trianto, Model Pembelajaran Terpadu, (Jakarta: Bumi Aksara, 2012)

Trianto, Mendesain Model Pembelajaran Inofatif Progressif, (Jakarta : Prenada Media Group, 2010) 